\title{
Successful Treatment of Recurrent Gastrointestinal Bleeding Due to Small Intestine Angiodysplasia and Multiple Myeloma with Thalidomide: Two Birds with One Stone
}

\author{
İnce Barsak Anjiyodisplazi ve Multipl Miyeloma Bağlı Gelişen Tekrarlayan Gastrointestinal \\ Kanamanın Talidomid ile Başarılı Tedavisi: Bir Taşla Iki Kuş
}

(D) Ida Hude1, (D) Josip Batinić1,2, (D) Sandra Bašić Kinda1, (D) Dražen Pulanić1,2,3

1 University Hospital Center Zagreb, Department of Internal Medicine, Division of Hematology, Zagreb, Croatia

2University of Zagreb Faculty of Medicine, Zagreb, Croatia

3Josip Juraj Strossmayer University of Osijek Faculty of Medicine, Osijek, Croatia

To the Editor,

Gastrointestinal angiodysplasia (GIA) is the most common digestive tract vascular malformation, often causing recurrent gastrointestinal bleeding. Despite association with certain hereditary diseases $[1,2,3]$, most GIAs are acquired, associated with aortic stenosis, hemodialysis, malignancies, or liver cirrhosis or idiopathic, and they appear among the elderly (>60 years) [4]. Advances in endoscopy brought about management improvements, but due to numerous lesions disseminated over the digestive tract, treatment of GIA remains a clinical challenge. Novel studies suggested that the use of thalidomide might be beneficial in these patients due to its antiangiogenic properties $[5,6]$. Thalidomide and its modern analogues currently represent a backbone treatment of another disease: multiple myeloma (MM) [7]. Here we would like to present a case of successful MM and GIA treatment with thalidomide.

Our male patient, born in 1947 and suffering from arterial hypertension, benign prostate hyperplasia, and chronic obstructive pulmonary disease, was diagnosed with symptomatic iron deficiency anemia in 2012. He underwent an extensive gastroenterological workup, which revealed multiple small intestine GIAs causing recurrent bleeding. Several attempts at endoscopic argon-plasma coagulation in the following years were not able to control the disease and the patient required regular blood transfusions (every 3-4 weeks) and parenteral iron supplementation. The patient was referred to a hematologist in 2016 for further assessment. Bleeding disorders were excluded (Table 1), but advanced immunoglobulin G kappa MM was found (ISS 1, with 20\%-25\% clonal plasma cells in the bone marrow and multiple osteolytic lesions), with no signs of bone marrow or gastrointestinal amyloidosis. Treatment with cyclophosphamide (500 mg/week), thalidomide (100 mg/day), and dexamethasone (40 mg/week) together with monthly zoledronate was initiated in March 2016. Cyclophosphamide was discontinued after 3 applications due to development of paroxysmal atrial fibrillation, requiring thromboprophylaxis with enoxaparin. Six months after treatment initiation the

Table 1. Relevant laboratory findings at baseline and during thalidomide treatment.

\begin{tabular}{|c|c|c|c|c|}
\hline $\begin{array}{l}\text { Key laboratory } \\
\text { findings }\end{array}$ & $\begin{array}{l}\text { Baseline } \\
\text { (2/2016) }\end{array}$ & $8 / 2016$ & $2 / 2017$ & $11 / 2017$ \\
\hline Hemoglobin $(\mathrm{g} / \mathrm{L})$ & 77 & 95 & 117 & 127 \\
\hline MCV (fL) & 71 & 84.1 & 85.7 & 90.9 \\
\hline $\mathrm{Fe}(\mu \mathrm{mol} / \mathrm{L})$ & 2 & 5 & 5 & 19 \\
\hline Ferritin $(\mu \mathrm{g} / \mathrm{L})$ & $<5$ & 25.1 & 23.8 & 184.8 \\
\hline PT & 1.13 & NA & NA & NA \\
\hline aPTा (s) & 22.7 & NA & NA & NA \\
\hline Fibrinogen $(\mathrm{g} / \mathrm{L})$ & 4.0 & NA & NA & NA \\
\hline VWF (\%) & 154 & NA & NA & NA \\
\hline FVIII (kIU/L) & 2.80 & NA & NA & NA \\
\hline FXIII (kIU/L) & 0.85 & NA & NA & NA \\
\hline $\begin{array}{l}\text { Total serum protein } \\
(\mathrm{g} / \mathrm{L})\end{array}$ & 72 & 66 & 67 & 68 \\
\hline $\begin{array}{l}\text { Total serum IgG } \\
\text { (g/L) }\end{array}$ & $\begin{array}{l}18.93 \\
\text { (high) }\end{array}$ & $\begin{array}{l}11.8 \\
\text { (normal) }\end{array}$ & $\begin{array}{l}13.09 \\
\text { (normal) }\end{array}$ & $\begin{array}{l}14.37 \\
\text { (normal) }\end{array}$ \\
\hline $\begin{array}{l}\text { M protein by } \\
\text { immunofixation } \\
\text {-serum IgG kappa }\end{array}$ & Present & Present & Present & Present \\
\hline $\begin{array}{l}\text { Serum free light- } \\
\text { chains (mg/L), kappa }\end{array}$ & 26.3 & 13.2 & 19.6 & 20.5 \\
\hline $\begin{array}{l}\text { Serum free light- } \\
\text { chains (mg/L), } \\
\text { lambda }\end{array}$ & 21.0 & 10.2 & 14.6 & 17.7 \\
\hline $\begin{array}{l}\text { Kappa/lambda ratio } \\
\text { serum }\end{array}$ & $\begin{array}{l}1.25 \\
\text { (normal) }\end{array}$ & $\begin{array}{l}1.29 \\
\text { (normal) }\end{array}$ & $\begin{array}{l}1.34 \\
\text { (normal) }\end{array}$ & $\begin{array}{l}1.16 \\
\text { (normal) }\end{array}$ \\
\hline M protein-urine & NA & NA & Negative & Negative \\
\hline $\begin{array}{l}\text { Bone marrow } \\
\text { plasma cell count } \\
(\%)\end{array}$ & $20-25$ & $<5$ & NA & NA \\
\hline \multicolumn{5}{|c|}{$\begin{array}{l}\text { MCV: Mean cell volume, PT: prothrombin time, aPTT: activated partial thromboplastin } \\
\text { time, VWF: Von Willebrand disease, Fe: serum iron, FVIII: factor VIII, FXIII: factor XIII, } \\
\text { IgG: immunoglobulin G, NA: not applicable. }\end{array}$} \\
\hline
\end{tabular}


patient achieved a very good partial remission (vgPR) of MM. Owing to age, comorbidities, and the patient's preferences, he was considered transplant-ineligible and so thalidomide (100 $\mathrm{mg} /$ day) and dexamethasone (20 mg/week) were continued. The patient has had no apparent bleeding since March 2016, he has been transfusion-free since October 2016, and he received the last parenteral iron supplementation in October 2017, so GIA endoscopy was not repeated. MM evaluations revealed continuous vgPR after 22 months of treatment; the patient is asymptomatic, suffers no side effects, and continues with thalidomide maintenance (Table 1).

The efficacy of thalidomide as a first-line treatment in combination regimens and as maintenance therapy for MM is well established [8]. Despite the irrefutable success of some novel therapeutic agents, such as proteasome inhibitors and next-generation immunomodulatory drugs, thalidomide still represents a valid treatment choice, especially in countries with limited healthcare resources. Thalidomide has an emerging role in GIA treatment, with shown efficacy in a small randomized trial [5] and multiple case reports (nicely reviewed by Bauditz [6]). Certain patients, especially those with several susceptible conditions as in the case presented here, seem to achieve utmost clinical benefit and improvement in quality of life. The optimal dosage of thalidomide in GIAs is currently not defined, and the side-effect profile might limit its long-term use for disease control. Nevertheless, its efficacy and side-effect manageability make further research worthwhile.

Keywords: Thalidomide, Angiodysplasia, Recurrent bleeding, Multiple myeloma, Antiangiogenic
Anahtar Sözcükler: Talidomid, Anjiodisplazi, Tekrarlayan kanama, Multipl myelom, Antianjiojenik

Conflict of Interest: The authors of this paper have no conflicts of interest, including specific financial interests, relationships, and/or affiliations relevant to the subject matter or materials included.

\section{References}

1. Makris M, Federici $A B$, Mannucci PM, Bolton-Maggs PH, Yee $\Pi$, Abshire $T$, Berntorp E. The natural history of occult or angiodysplastic gastrointestinal bleeding in von Willebrand disease. Haemophilia 2015;21:338-342.

2. Duarte BKL, de Souza SM, Costa-Lima C, Medina SS, Ozelo MC. Thalidomide for the treatment of gastrointestinal bleeding due to angiodysplasia in a patient with Glanzmann's thrombasthenia. Hematol Rep 2017;9:6961.

3. Alam MA, Sami S, Babu S. Successful treatment of bleeding gastro-intestinal angiodysplasia in hereditary haemorrhagic telangiectasia with thalidomide. BMJ Case Rep 2011:2011.

4. Becq A, Rahmi G, Perrod G, Cellier C. Hemorrhagic angiodysplasia of the digestive tract: pathogenesis, diagnosis, and management. Gastrointest Endosc 2017;86:792-806

5. Ge ZZ, Chen HM, Gao YJ, Liu WZ, Xu CH, Tan HH, Chen HY, Wei W, Fang JY, Xiao SD. Efficacy of thalidomide for refractory gastrointestinal bleeding from vascular malformation. Gastroenterology 2011;141:1629-1637.

6. Bauditz J. Effective treatment of gastrointestinal bleeding with thalidomide - chances and limitations. World J Gastroenterol 2016;22:3158-3164.

7. Kumar SK, Vij R, Noga SJ, Berg D, Brent L, Dollar L, Chari A. Treating multiple myeloma patients with oral therapies. Clin Lymphoma Myeloma Leuk 2017; 17:243-251.

8. Aguiar PM, de Mendonça Lima T, Colleoni GWB, Storpirtis S. Efficacy and safety of bortezomib, thalidomide, and lenalidomide in multiple myeloma: an overview of systematic reviews with meta-analyses. Crit Rev Oncol Hematol 2017;113:195-212.

This study was previously presented as a poster in the Croatian language at the $7^{\text {th }}$ Croatian Congress of Hematologists in Šibenik, Croatia, in September 2017. 